\title{
Eco-Culture: Suatu Model Pembelajaran Ekonomi Berorientasi Peduli Lingkungan
}

\author{
Rahmatullah \\ Fakultas Ekonomi Universitas Negeri Makassar \\ Email: rahmatullah@unm.ac.id
}

(Received: 25 Maret 202; Accepted: 15 April 2021; Published: 30 Juli 2021)

\begin{abstract}
This study aims to describe how economic education that takes place in schools can foster a character of caring for the environment in students, and formulate values that care for the environment that can be internalized in economic subject matter. The method used in this study is a research and development method with reference to the systems approach according to Dick and Carey. The stages in this research consist of the initial needs analysis stage, the identification of economic material to be developed, the development process, the compilation and production stages, and the product testing and revision stages. The results show that the character of caring for the environment needs to be integrated into economic subject matter in order to form an understanding, attitude and behavior that cares about the environment which is implemented in various human economic activities such as production activities and consumption activities. In simple terms, economic activities carried out by humans will have an impact on the environment, both as providers of resources for satisfying needs and as objects affected by human economic activities.
\end{abstract}

Keyword: Economic Learning; Student Awareness, Eco-Culture; Economic activity

\begin{abstract}
Abstrak. Penelitian ini bertujuan untuk mendeskripsikan bagaimana pendidikan ekonomi yang berlangsung disekolah dapat menumbuhkan karakter peduli lingkungan pada siswa, serta merumuskan nilai-nilai peduli lingkungan yang dapat diinternalisasi dalam materi pelajaran ekonomi. Metode yang digunakan dalam penelitian ini adalah metode penelitian dan pengembangan dengan mengacu pada pendekatan sistem menurut Dick dan Carey. Tahapan dalam penelitian ini terdiri dari tahap analisis kebutuhan awal, identifikasi materi ekonomi yang akan dikembangkan, proses pengembangan, tahap kompilasi dan produksi, serta tahap uji coba dan revisi produk. Hasil penelitian menunjukkan bahwa karakter peduli lingkungan perlu diintegrasikan kedalam materi pelajaran ekonomi sehingga terbentuk pemahaman, sikap dan perilaku peduli lingkungan yang diimplementasikan dalam berbagai kegiatan ekonomi manusia seperti kegiatan produksi maupun kegiatan konsumsi. Secara sederhana, kegiatan ekonomi yang dilakukan oleh manusia akan berdampak pada lingkungan, baik sebagai penyedia sumber daya pemuas kebutuhan maupun sebagai objek yang terkena dampak dari aktifitas ekonomi manusia.
\end{abstract}

Kata Kunci: Pembelajaran Ekonomi; Kesadaran Siswa, Karakter Peduli Lingkungan; Kegiatan Ekonomi

\section{PENDAHULUAN}

Pelaksanaan pendidikan bertujuan membentuk karakter peserta didik untuk menjadi manusia yang mulia, bertanggung jawab, dan memiliki pengetahuan sesuai dengan tuntutan perkembangan ilmu pengetahuan dan teknologi. Keberhasilan penyelenggaraan pendidikan tidak hanya dilihat dari aspek pengetahuan (kognitif), tetapi juga dilihat dari aspek sikap (afektif) dan keterampilan (psikomotorik). Ketiga aspek tersebut perlu dirancang dan diarahkan untuk mewujudkan manusia yang berkualitas dalam mendukung pembangunan berkelanjutan di sektor ekonomi, sosial dan lingkungan. Untuk itu, pendidikan berperan penting dalam mewujudkan manusia yang berkualitas dan berkarakter sebagaimana yang diharapkan dalam mewujudkan pembangunan berkelanjutan. 
Pembangunan berkelanjutan memandang pentingnya sumber daya manusia yang memiliki kepedulian akan kelestarian alam dan lingkungan sehingga dapat dinikmati bukan hanya oleh generasi masa kini akan tetapi dapat diwariskan untuk generasi yang akan datang. Sumber daya manusia yang seperti itu dapat terwujud melalui penyelenggraan pendidikan yang berkarakter khususnya disekolah formal. Karakter yang penting untuk dikembangkan dan mendukung pembangunan berkelanjutan adalah karakter peduli lingkungan.

Karakter peduli lingkungan penting untuk dikaji agar tumbuh kesadaran pada diri manusia akan pentingnya kelestarian sumber daya alam dan lingkungan. Kelestarian sumber daya alam dan lingkungan akan membawa dampak positif dalam kehidupan utamanya terkait dengan berbagai aktifitas ekonomi manusia dalam pemenuhan kebutuhan hidupnya. Aktifitas ekonomi manusia mulai dari kegiatan produksi sampai pada kegiatan konsumsi sangat berkaitan erat dengan lingkungan, baik sebagai penyedia sumber bahan baku produksi maupun sebagai objek yang terkena dampak dari berbagai aktifitas ekonomi manusia. Dengan demikian, nilai-nilai peduli lingkungan perlu dintegrasikan dalam pendidikan khususnya pendidikan ekonomi agar terwujud sumber daya manusia yang memiliki kesadaran dan kepedulian terhadap lingkungan, sehingga dapat mencegah terjadinya krisis ekologi.

Krisis ekologi muncul akibat adanya sikap dan perilaku manusia dalam kehidupan ekonomi yang cenderung eksploitatif, sehingga menyebabkan terjadinya berbagai masalah lingkungan seperti pemanasan global, banjir, kekeringan, pencemaran lingkungan, dan berbagai bentuk kerusakan lingkungan lainnya. Hal ini tentu saja akan menyebabkan kesejahteraan masyarakat, kehidupan sosial budaya dan kelestarian alam dan lingkungan semakin menurun. Untuk itu, kepedulian lingkungan perlu dikembangkan di dunia pendidikan, agar dapat menumbuhkan generasi yang dapat mempertahankan dan meningkatkan kondisi lingkungan yang ada (Taufiq, 2014).

Selain itu, pendidikan dapat berperan dalam membentuk manusia agar dapat berpikir sesuai dengan etika berkelanjutan, sehingga tujuan membuat warga bertanggung jawab terhadap lingkungan akan lebih mudah dicapai (Hungerford dan Volk di Putrawan, 2014). Oleh karena itu, program pendidikan dapat berkontribusi untuk kesejahteraan masyarakat, sehingga proses pembangunan dapat dilaksanakan secara berkelanjutan.

Pendidikan sangat penting dalam konteks pembangunan berkelanjutan karena pendidikan adalah sarana untuk mengubah persepsi, sikap dan perilaku manusia (Priyanto, 2013). Perilaku manusia yang diharapkan adalah yang dapat memberikan manfaat sosial, manfaat ekonomi, dan memastikan keberlanjutan ekologis. Hubungan antara ekonomi manusia dan perilaku ekologis dijelaskan oleh Prugh (1995), bahwa dalam memenuhi kebutuhan mereka, manusia harus memperhatikan ekologi dengan memanfaatkan sumber daya alam secara bertanggung jawab dan menjaga jarak dari perspektif bebas nilai.

Hubungan di atas memberikan pesan tentang nilai-nilai lingkungan yang harus dipertimbangkan dalam semua tindakan ekonomi, sebagaimana Wahjoedi (2014) berpendapat bahwa perilaku ekonomi diarahkan untuk menghormati dan menjaga keseimbangan alam dan lingkungan, kembali ke alam, tidak merusak alam. Satu hal yang dapat dilakukan untuk mengatasi krisis budaya ekologis adalah menciptakan perubahan mendasar dalam perspektif dan perilaku manusia, yang dimulai dengan pengetahuan tentang pentingnya nilainilai eko-budaya.

Nilai-nilai eco-culture harus diinternalisasi dalam pembelajaran ekonomi untuk menumbuhkan kesadaran siswa tentang pentingnya pelestarian sumber daya alam dan lingkungan, sehingga semua orang dapat berperilaku secara rasional dan bertanggung jawab. Harus ditekankan bahwa sumber daya alam dan lingkungan tidak hanya milik generasi sekarang tetapi juga generasi masa depan. Oleh karena itu, kedua generasi memiliki kepedulian terhadap pelestarian sumber daya alam dan lingkungan, sehingga proses pembangunan dapat dilakukan secara berkelanjutan.

Pendidikan karakter bertujuan untuk menghasilkan sumber daya manusia berkualitas. Sumber daya manusia yang berkualitas tinggi akan lahir dari orang yang religius, percaya diri, dan memiliki etos kerja yang tinggi (Poespowardojo dan Hardjatno, 2010). Sumber daya manusia semacam ini akan menjalankan dan mengimplementasikan program-program negara serta pelaku pembangunan, yang lebih berorientasi pada kesejahteraan masyarakat dalam rangka meningkatkan martabat bangsa (Nugroho, 2010). 
Menurut Kesuma (2011), pendidikan karakter bertujuan untuk menanamkan dan mengembangkan karakter kepada peserta didik, sehingga mereka memiliki karakter yang mulia, menerapkan dan mempraktikkannya dalam kehidupan sehari-hari baik dalam keluarga, sebagai anggota masyarakat dan warga negara. Poin utama pendidikan karakter menurut Budiansyah (2010) terdiri dari kebaikan, berpikir baik, mengatakan baik, dan berperilaku baik.
Lickona (1991) mengemukakan bahwa karakter berkaitan dengan konsep moral (moral mengetahui), sikap moral (moral felling), dan perilaku moral. Berdasarkan ketiga komponen ini, dapat dinyatakan bahwa karakter yang baik didukung oleh pengetahuan tentang kebaikan, keinginan untuk berbuat baik, dan melakukan perbuatan baik. Hubungan ketiga hal ini dapat dilihat pada gambar berikut:

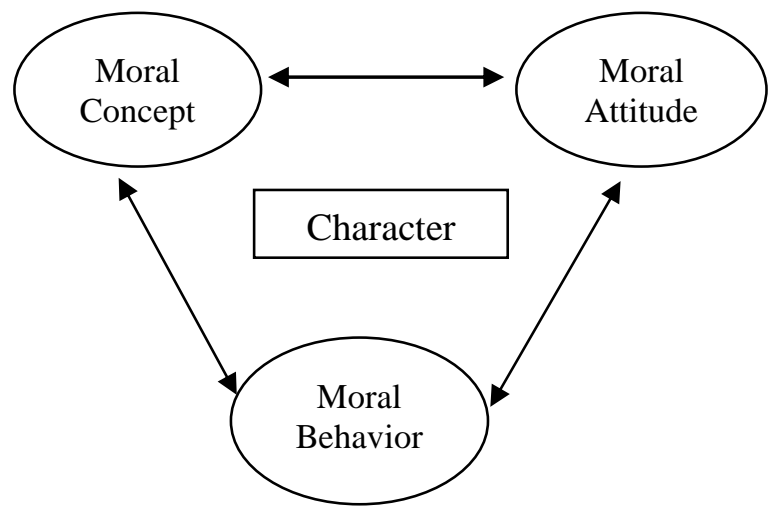

Gambar 1. Hubungan antara komponen moral dalam pembangunan karakter menurut Lickona, 1991.

Pendidikan karakter dilaksanakan melalui pendekatan holistik, yang mengintegrasikan pengembangan karakter ke dalam setiap aspek kehidupan sekolah. Berikut adalah karakteristik pendekatan holistik (Elkind dan Sweet, 2004).

1. Segala sesuatu di sekolah diatur berdasarkan pengembangan hubungan antara siswa, guru dan masyarakat,

2. Sekolah adalah komunitas pelajar yang peduli di mana ada ikatan yang jelas yang menghubungkan siswa, guru, dan sekolah,

3. Pembelajaran emosional dan sosial setara dengan pembelajaran akademik.

4. Kerjasama dan kolaborasi di antara siswa menjadi lebih penting daripada kompetisi,

5. Nilai-nilai seperti keadilan, rasa hormat, dan kejujuran menjadi bagian dari pembelajaran sehari-hari baik di dalam maupun di luar kelas,

6. Siswa diberi banyak kesempatan untuk mempraktikkan perilaku moral mereka melalui kegiatan seperti belajar menyediakan layanan,

7. Disiplin dan manajemen kelas adalah fokus dalam pemecahan masalah daripada hadiah dan hukuman,

8. Model pembelajaran yang berpusat pada guru harus ditinggalkan dan diubah menjadi ruang kelas yang demokratis di mana guru dan siswa berkumpul untuk membangun kesatuan, norma, dan penyelesaian masalah.

Istilah eco-culture terdiri dari dua kata yaitu 'eco' dan 'cultur'. Kata 'eco or oikos' berarti rumah, habitat atau lingkungan yang terkait dengan ekologi. Sedangkan 'budaya' berarti budaya yang dalam hal ini berkaitan dengan ekologi manusia. Dari istilah itu, Candase Gossen mendefinisikan bahwa eco-culture berarti kebangkitan karakter pengetahuan tentang ecoculturepada generasi muda untuk diintegrasikan dalam kehidupan masyarakat. Selain itu, menurut Janhonen et al (2006), eco-culture atau ekologibudaya terkait dengan bagaimana keluarga proaktif dalam mengubah rutinitas sehari-hari sebagai akibat dari perubahan lingkungan, baik di lingkungan global maupun lokal.

Nilai-nilai lingkungan (eco-culture) penting untuk diinternalisasi dalam pembelajaran ekonomi di sekolah. Ini adalah upaya untuk mempersiapkan dan memberdayakan siswa sebagai generasi bangsa, untuk mengambil tanggung jawab untuk menciptakan masa depan yang berkelanjutan (Gough, et al., 2005). Selain itu, ini bisa menjadi awal pembangunan karakter pengetahuan tentang eco-culture di generasi muda, yang akan diimplementasikan dalam kegiatan ekonomi sehari-hari. Perubahan perilaku 
manusia yang terkait dengan pentingnya nilainilai eco-culture dapat didahului dengan memberikan pemahaman tentang pentingnya keberadaan manusia, dengan penekanan bahwa manusia adalah bagian dari ekosistem (Setiaji, 2014).

Kebiasaan ekonomi atau perilaku manusia dalam mengelola sumber daya alam dan lingkungan cenderung bersifat antroposentris, sehingga timbul berbagai masalah lingkungan (Halid, dkk 2014). Perilaku atau kebiasaan semacam itu adalah manifestasi dari pengetahuan dan cara berpikir dari pengalaman pendidikan masa lalu, yang cenderung mengabaikan keberlanjutan sumber daya alam dan lingkungan, sumber daya sosial budaya, dan sumber daya ekonomi.

Hasil penelitian yang dilakukan oleh Priyanto, et al. (2013) menggambarkan bahwa ada hubungan antara sikap dan perilaku ecoculture dengan paradigma pendidikan untuk pembangunan berkelanjutan. Penelitian ini menekankan pentingnya sikap eco-culture dan perilaku eco-culture sebagai upaya mewujudkan pembangunan berkelanjutan. Sikap eco-culture dan perilaku eco-culture dapat diwujudkan dalam bentuk tindakan nyata terkait dengan kegiatan ekonomi manusia dalam kehidupan sehari-hari.

Implementasi nilai-nilai eco-culture perlu melibatkan partisipasi semua komponen pendidikan dalam lingkungan sekolah. Menurut Hyvinkaa \& Riihimaki, (2003), partisipasi semua komponen pendidikan bertujuan untuk mewujudkan keberlanjutan dari kedua aspek ekologis (keberlanjutan ekologis), aspek sosial (keberlanjutan sosial), dan aspek ekonomi (keberlanjutan ekonomi).

\section{METODE}

Metode yang digunakan didasarkan pada pendekatan penelitian dan pengembangan Dick and Carey (2001). Pengembangan didefinisikan sebagai proses menerjemahkan atau menggambarkan spesifikasi desain ke dalam bentuk fisik (Seels, et al., 1994). Istilah lain yang terkait dengan ini adalah desain pembelajaran. Menurut Heinich et al (2002), desain pembelajaran adalah proses menganalisis kebutuhan, menentukan konten apa yang harus dikuasai, menentukan tujuan pendidikan, merancang bahan untuk mencapai tujuan tertentu, dan melakukan uji coba dan merevisi program yang berhubungan dengan hasil pembelajaran. .

Tahapan penelitian dan pengembangan dirancang selama 2 tahun, tetapi studi dalam artikel ini hanya berisi hasil penelitian di tahun pertama. Secara umum, uraian tahapan penelitian adalah sebagai berikut: (1) Perlu analisis bahan ekonomi yang akan dikembangkan; (2) Identifikasi bahan ekonomi yang akan dikembangkan; (3) Proses pengembangan; (4) Fase Kompilasi dan produksi bahan ekonomi eko-budaya, yang terdiri dari silabus, rencana implementasi pembelajaran, modul / bahan, dan lembar aktivitas siswa; (5) Uji coba dan revisi produk, termasuk penilaian atau tanggapan ahli desain pembelajaran, praktisi ekonomi / guru, uji coba terbatas, dan uji coba lapangan. Tahapantahapan tersebut disajikan dalam gambar berikut:

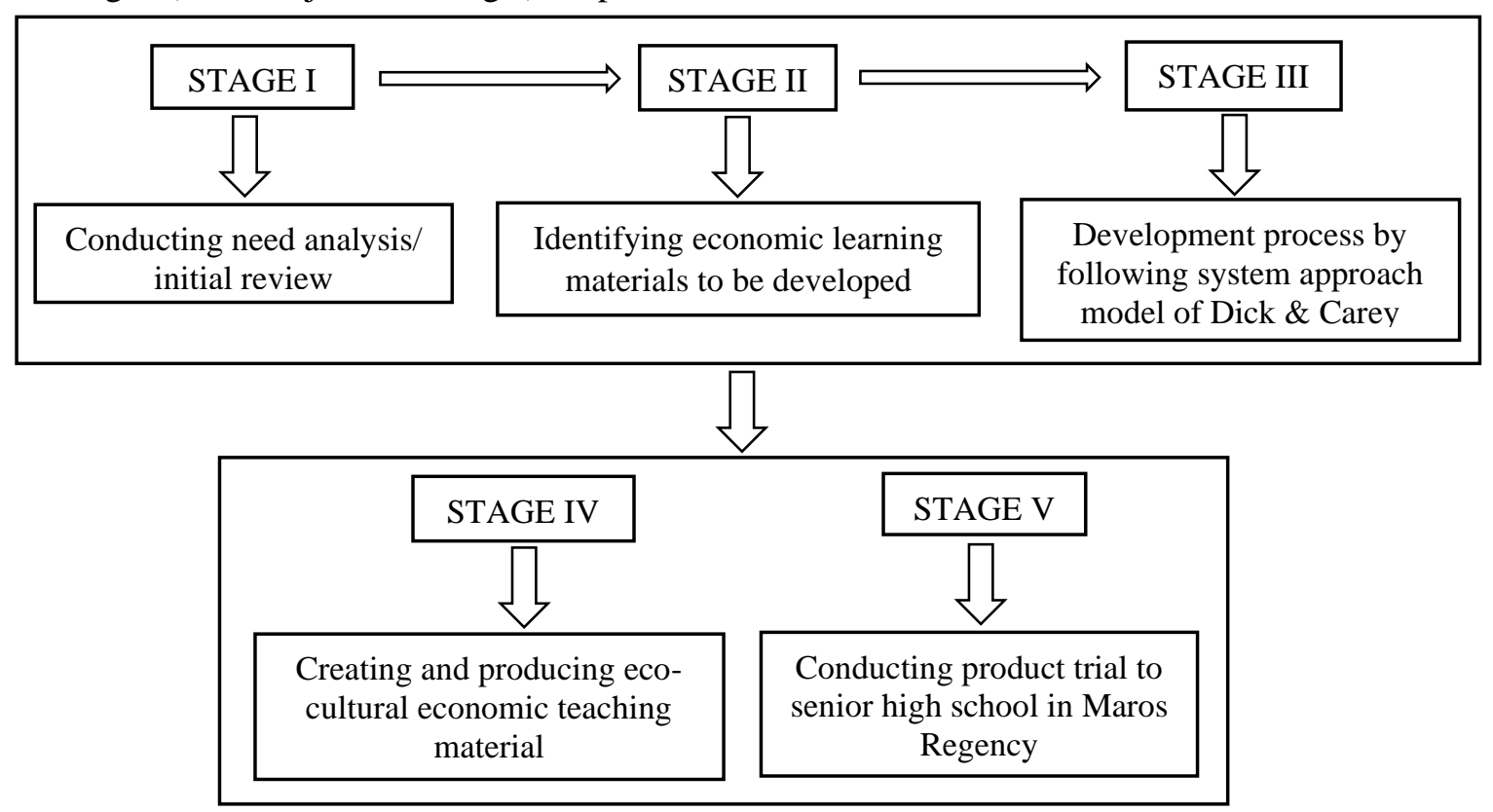

Figure 2. Research and Development Stage 


\section{HASIL DAN PEMBAHASAN}

Untuk menerapkan nilai-nilai eco-culture dalam pembelajaran ekonomi, perlu dirumuskan nilai-nilai eco-culture dan bahan pembelajaran yang akan dikembangkan.

\section{A. Nilai-Nilai Lingkungan}

Nilai-nilai eco-culture yang akan diinternalisasi dalam pembelajaran ekonomi dapat disajikan dalam tabel berikut:

Tabel 1. Nilai-Nilai Eco-Culture

\begin{tabular}{|c|c|}
\hline Nilai Fundamental & $\begin{array}{c}\text { Nilai Praktis } \\
\text { (Karakter Eco-Culture) }\end{array}$ \\
\hline $\begin{array}{l}\text { 1. Religius } \\
\text { 2. Saling menghormati } \\
\text { 3. Tidak memaksakan } \\
\text { kehendak } \\
\text { 4. Kasih sayang } \\
\text { 5. Saling menghargai } \\
\text { 6. Jujur } \\
\text { 7. Kepedulian sosial } \\
\text { 8. Cinta tanah air } \\
\text { 9. Kebersamaan } \\
\text { 10. Gotong royong } \\
\text { 11. Bertanggung jawab } \\
\text { 12. Tulus dan Ikhlas } \\
\text { 13. Kekeluargaan } \\
\text { 14. Kreatifitas } \\
\text { 15. Kemandirian }\end{array}$ & $\begin{array}{l}\text { 1. Mensyukuri ketersediaan SDA sebagai karunia Tuhan } \\
\text { Yang Maha Esa } \\
\text { 2. Membuang sampah pada tempatnya, sehingga tidak } \\
\text { mencemari darat, laut dan udara. } \\
\text { 3. Tidak menggunakan bahan kimia untuk menangkap ikan } \\
\text { 4. Tidak menebang pohon dihutan secara berlebihan } \\
\text { (illegal loging) } \\
\text { 5. Melakukan penanaman pohon/reboisasi hutan } \\
\text { 6. Melakukan penanaman pohon bakau agar terhindar dari } \\
\text { erosi } \\
\text { 7. Tidak melakukan pembakaran hutan } \\
\text { 8. Menggunakan air bersih sesuai kebutuhan } \\
\text { 9. Tidak melakukan pembakaran sampah sebab mencemari } \\
\text { udara } \\
\text { 10. Mengkonsumsi barang-barang produksi lokal } \\
\text { 11. Tidak merusak kawasan hutan lindung dan konservasi } \\
\text { 12. Bersama-sama membersihkan saluran air dari sampah } \\
\text { 13. Perlunya daerah resapan air untuk kepentingan } \\
\text { bersama } \\
\text { 14. Membersihkan pekarangan dari sampah/dedaunan } \\
\text { 15. Mematikan alat-alat elektronik jika tidak digunakan }\end{array}$ \\
\hline
\end{tabular}

Sumber: Dikembangkan oleh peneliti

\section{B. Topik Materi}

Setelah nilai-nilai eco-culture dirumuskan, topik materi pembelajaran ekonomi yang akan dikembangkan diidentifikasi. Bahanbahan yang diformulasikan menjadi suplemen pembelajaran. Formulasi bahan disajikan dalam tabel berikut.

Tabel 2. Topik Materi Pembelajaran ekonomi Eco-Culture

\begin{tabular}{|c|c|c|}
\hline $\begin{array}{l}\text { STANDAR } \\
\text { KOMPETENSI }\end{array}$ & $\begin{array}{l}\text { KOMPETENSI } \\
\text { DASAR }\end{array}$ & $\begin{array}{c}\text { MATERI } \\
\text { PEMBELAJARAN }\end{array}$ \\
\hline \multirow[t]{3}{*}{$\begin{array}{l}\text { Memahami konsep } \\
\text { dasar Ekonomi }\end{array}$} & $\begin{array}{l}\text { Menjelaskan pengertian } \\
\text { dan ruang lingkup ilmu } \\
\text { ekonomi }\end{array}$ & $\begin{array}{ll}- & \text { Pengertian ilmu ekonomi, } \\
- & \text { Ruang lingkup ilmu ekonomi, } \\
\text { - } & \text { Metode ilmu ekonomi. }\end{array}$ \\
\hline & $\begin{array}{l}\text { Masalah Ekonomi dan } \\
\text { Pemecahannya }\end{array}$ & $\begin{array}{ll}- & \text { Kebutuhan dan keinginan manusia, } \\
\text { - } & \text { Kelangkaan dan pilihan, } \\
\text { - } & \text { Kebutuhan manusia Vs ketersediaan } \\
& \text { sumber daya. }\end{array}$ \\
\hline & $\begin{array}{l}\text { Mendeskripsikan } \\
\text { perilaku ekonomi } \\
\text { manusia terhadap } \\
\text { lingkungannya }\end{array}$ & $\begin{array}{ll}- & \text { Dasar moral ekonomi, } \\
\text { - } & \text { Dampak yang ditimbulkan oleh perilaku } \\
& \text { manusia terhadap lingkungannya. }\end{array}$ \\
\hline \multirow{2}{*}{$\begin{array}{l}\text { Memahami Nilai- } \\
\text { nilai Dasar } \\
\text { Ekonomi } \\
\text { Lingkungan }\end{array}$} & $\begin{array}{l}\text { Menjelaskan Pengertian } \\
\text { Ekonomi Lingkungan } \\
\text { dan Green Economy }\end{array}$ & $\begin{array}{ll}\text { - } & \text { Ekonomi lingkungan dan green economy, } \\
\text { - } & \text { Manusia dan lingkungannya }\end{array}$ \\
\hline & $\begin{array}{l}\text { Menjelaskan konsep } \\
\text { pembangunan ekonomi }\end{array}$ & 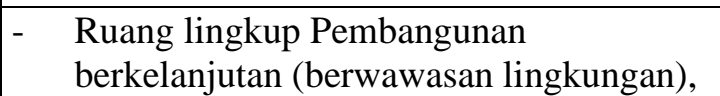 \\
\hline
\end{tabular}


Rahmatullah, Eco-Culture: Suatu Model Pembelajaran Ekonomi...| 76

\begin{tabular}{|c|c|c|}
\hline & $\begin{array}{l}\text { berwawasan lingkungan } \\
\text { (Sustainable } \\
\text { Development) }\end{array}$ & $\begin{array}{l}\text { Kemandirian dan ketidakmandirian } \\
\text { pembangunan }\end{array}$ \\
\hline & $\begin{array}{l}\text { Menjelaskan etika } \\
\text { manusia yang } \\
\text { berwawasan lingkungan }\end{array}$ & $\begin{array}{ll}\text { - } & \text { Etika manusia terhadap lingkungan } \\
\text { - } & \text { Prinsip-prinsip etika manusia terhadap } \\
\text { lingkungan } \\
\text { - } \\
\text { Pengetahuan, sikap dan perilaku manusia } \\
\text { yang berwawasan lingkungan }\end{array}$ \\
\hline & $\begin{array}{l}\text { Mendeskripsikan } \\
\text { pengetahuan dan sikap } \\
\text { peduli lingkungan (eco- } \\
\text { culture }) \text { dalam kegiatan } \\
\text { ekonomi konsumen dan } \\
\text { produsen }\end{array}$ & $\begin{array}{ll}\text { - } & \text { Circulair Flow Diagram dalam kegiatan } \\
\text { ekonomi peduli lingkungan } \\
\text { - } \\
\text { Perilaku Produsen Dan Konsumen } \\
\text { Berwawasan Lingkungan }\end{array}$ \\
\hline \multirow[t]{3}{*}{$\begin{array}{l}\text { Aplikasi Ekonomi } \\
\text { Lingkungan } \\
\text { dalam kegiatan } \\
\text { ekonomi }\end{array}$} & $\begin{array}{l}\text { Mengidentifikasi } \\
\text { perilaku ekonomi } \\
\text { manusia sadar } \\
\text { lingkungan (eco-culture) }\end{array}$ & $\begin{array}{ll}\text { - } & \text { Makna dan nilai-nilai peduli lingkungan } \\
\text { dalam kehidupan ekonomi } \\
\text { - } & \text { Wujud perilaku sadar lingkungan }\end{array}$ \\
\hline & $\begin{array}{l}\text { Mendeskripsikan } \\
\text { Perilaku Sadar } \\
\text { Lingkungan (eco- } \\
\text { culture) Dalam } \\
\text { Pemanfaatan Sumber } \\
\text { Daya Alam }\end{array}$ &  \\
\hline & $\begin{array}{l}\text { Mendeskripsikan } \\
\text { perilaku sadar } \\
\text { lingkungan (eco-culture) } \\
\text { dalam kehidupan rumah } \\
\text { tangga }\end{array}$ &  \\
\hline $\begin{array}{l}\text { Ekonomi Global } \\
\text { yang Berwawasan } \\
\text { Lingkungan }\end{array}$ & $\begin{array}{l}\text { Menjelaskan pentingnya } \\
\text { pembangunan industri } \\
\text { yang berwawasan } \\
\text { lingkungan dan } \\
\text { berkeadilan. }\end{array}$ & $\begin{array}{ll}\text { - } & \text { Konsep industri yang berwawasan } \\
\text { lingkungan } \\
\text { - } \\
\text { Bagaimana mewujudkan kawasan } \\
\text { industri yang berwawasan lingkungan } \\
\text { - Jaringan industri yang berwawasan } \\
\text { lingkungan }\end{array}$ \\
\hline
\end{tabular}

Sumber: Dikembangkan oleh peneliti

Adapun gambaran prototype

model pembelajaran ekonomi berkarakter eco-culture dapat dilihat pada gambar berikut: 
Gambar 2. Rumusan Prototype Model Pembelajaran Ekonomi Berorientasi Peduli Lingkungan

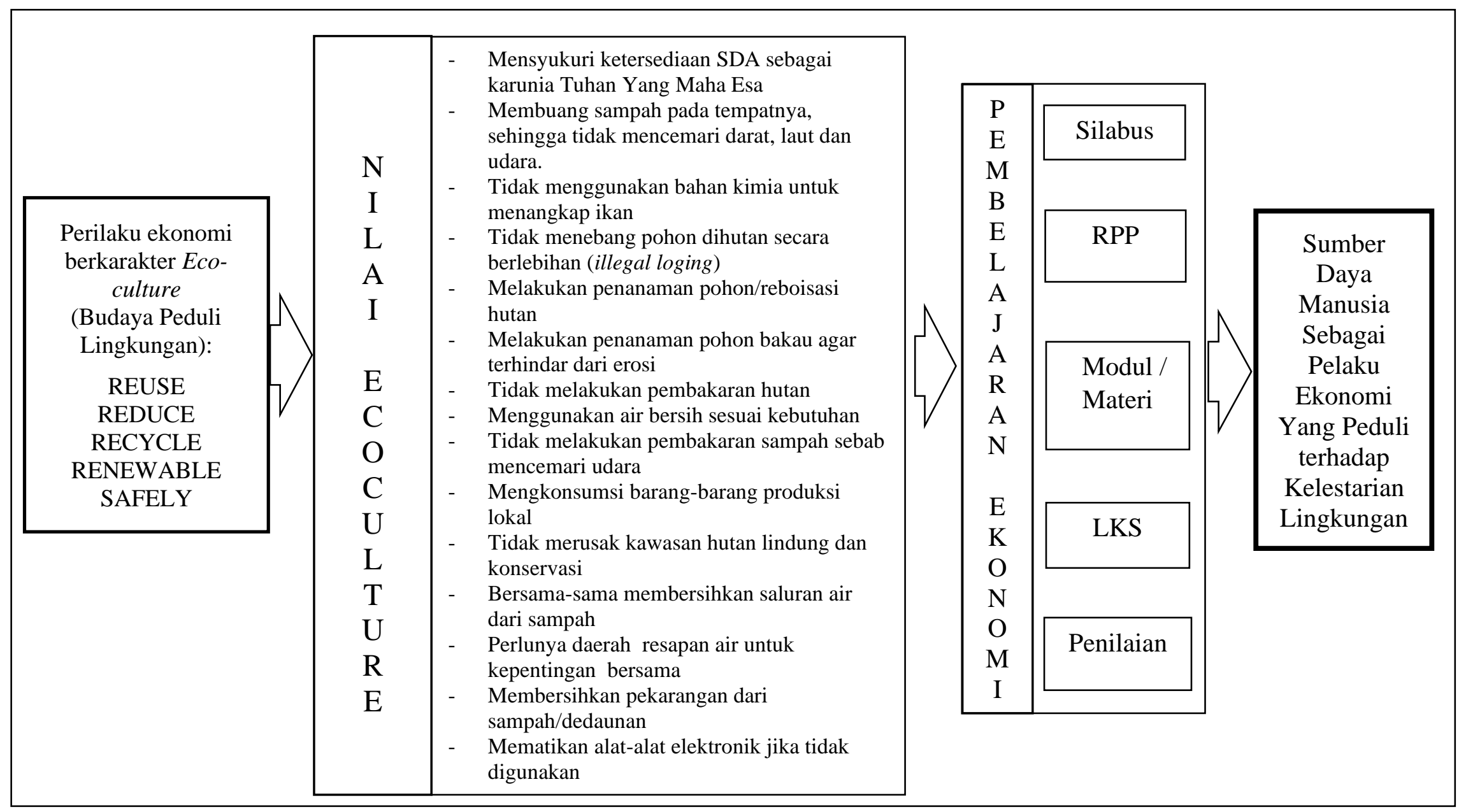


Hasil penelitian diperoleh bahwa model pembelajaran ekonomi berkarakter eco-culture dapat digunakan dalam kegiatan pembelajaran. Dari hasil kajian awal dan observasi, dapat disimpulkan bahwa pembelajaran ekonomi berkarakter eco-culture penting untuk dikembangkan sebagai bagian dari proses

\begin{tabular}{ccc} 
Validator & $\begin{array}{c}\text { Presentase } \\
\text { Penilaian }\end{array}$ & Kriteria \\
\hline Ahli Desain & $85,21 \%$ & $\begin{array}{l}\text { Perangkat pembelajaran yang dikembangkan sangat } \\
\text { baik dan tidak perlu direvisi }\end{array}$ \\
\hline
\end{tabular}

Sumber: Data diolah oleh peneliti

Hasil validasi ahli desain diperoleh presentase sebesar 82,21 persen. Hal ini berarti bahwa desain perangkat pembelajaran ekonomi berkarakter eco-culture termasuk dalam kriteria sangat baik. Hal tersebut bermakna bahwa model peningkatan kualitas dan kepedulian generasi muda terhadap kelestarian lingkungan untuk kebutuhan pendidikan ekonomi masa kini dan masa mendatang yang berkelanjutan.

Hasil Penilaian ahli desain pembelajaran dilihat pada tabel 3 berikut: yang dikembangkan memenuhi standard kelayakan untuk digunakan dalam tahap uji coba.

Hasil penilaian praktisi pembelajaran dapat dilihat pada tabel 4 berikut:

\begin{tabular}{|c|c|c|}
\hline Praktisi & $\begin{array}{c}\text { Presentase } \\
\text { Penilaian }\end{array}$ & Kriteria \\
\hline Praktisi 1 & $85,14 \%$ & Sangat baik \\
\hline Praktisi 2 & $86,85 \%$ & Sangat baik \\
\hline Praktisi 3 & $83,42 \%$ & Sangat baik \\
\hline Rata-rata & $85,14 \%$ & Sangat baik \\
\hline
\end{tabular}

Sumber: Data diolah oleh peneliti

Hasil Penilaian praktisi terhadap perangkat pembelajaran ekonomi berkarakter eco-culture untuk Sekolah Menengah Atas diperoleh presentase rata-rata sebesar 85,14 persen. Hal ini berarti bahwa perangkat pembelajaran ekonomi yang dikembangkan termasuk dalam kriteria sangat dan memenuhi standard kelayakan untuk digunakan dalam tahap uji coba lapangan.

Hasil uji coba terbatas yang dilakukan pada 30 orang siswa yang berasal dari tiga sekolah mitra (10 orang siswa SMA Negeri 1 Maros, 10 orang siswa SMA Negeri 4 Maros, dan 10 orang siswa SMA Negeri 11 Maros), maka diperoleh nilai rata-rata sebesar 84,67 persen. Hasil tersebut menunjukkan bahwa materi yang disajikan dalam perangkat pembelajaran ekonomi berkarakter eco-culture dikategorikan sangat baik. Dengan demikian dapat disimpulkan bahwa materi yang disajikan memiliki kesesuaian dengan kebutuhan siswa dalam pembelajaran ekonomi, dan selanjutnya dapat diuji cobakan pada skala yang lebih luas melalui uji coba lapangan.

Hasil uji coba materi pembelajaran ekonomi berkarakter eco-culture di SMA Negeri 1 Maros dikategorikan berhasil. Hal ini sesuai dengan perolehan nilai rata-rata Pretest dan 
jangka pendek, tetapi berorientasi pada tujuan jangka panjang atau keberlanjutan antar generasi.

Karakter eco-culture menjadi sesuatu yang penting untuk diinteralisasikan dalam pembelajaran ekonomi. Hal ini didasari oleh munculnya kesadaran atau keinginan untuk melakukan perubahan atas perilaku manusia yang bersifat konvensional terkait dengan masalah ekologi. Perilaku yang bersifat konvensional terhadap ekologi cenderung bersifat jangka pendek sehingga mengakibatkan munculnya berbagai dampak terhadap lingkungan. Hasil uji coba yang dilakukan pada sekolah menegah atas menunjukkan adanya respon yang positif dari para guru maupun siswa disekolah tempat uji coba. Hal ini ditunjukkan dengan peningkatan hasil tes yaitu kegiatan pretest dan postest.

Dalam mengimplementasikan model pembelajaran ekonomi berkarakter ecoculture di sekolah menengah atas, maka seluiruh komponen sekolah termasuk siswa diharapkan dapat mengaplikasikan nilai-nilai peduli lingkungan melalui perilaku ekonomi dalam kehidupan sehari-hari. Hal ini agar siswa sebagai generasi bangsa dapat menjadi pelaku ekonomi yang memiliki kepedulian terhadap lingkungan sebagai wujud kecintaan terhadap bangsa, dalam menghadapi globalisasi.

\section{DAFTAR PUSTAKA}

Budimansyah, Dasi. 2010. Penguatan Pendidikan Kewarganegaraan Untuk Mebangun Karakter Bangsa. Bandung: Aksara Press.

Dharmawan, A. H. 2007. Konsep-konsep Dasar dan Isu-Isu Kritikal Ekologi Manusia. Modul Kuliah Ekologi Manusia. Departemen Komunikasi dan Pengembangan Masyarakat. Bogor: Fakultas Ekologi Manusia IPB.

Dick, W. \& Carey, L. 2001.The Sistematic Design of Instruction: Third Edition. USA: Harper Collins Publishers.

Elkind, D. H. \& Sweet, F. 2004. How to Do Character Education. Today School, Sept/Oct 2004 Issue.

Gough, A., dkk.2005. Educating for a Sustainable Future, A National Environmental Education Statement for Australian Schools. ISBN 186366 5978, Australia: Curriculum Corporation.

Halid, I., dkk. 2014. Implementasi Nilai-Nilai Islam Dalam Sikap Ramah Lingkungan
Untuk Mewujudkan Masyarakat Sadar Lingkungan Melalui Gerakan Pondok Pesantren (Studi Kasus Di Pondok Pesantren Nurul Haramain NW Narmada Dan Pondok Pesantren Nurul Hakim Kediri Lombok Barat). Jurnal Ekosains, Volume VI No. 1 Maret 2014

Heinich, R. dkk 2002.Instructional Media and Technologies of learning. New Jersey: Pearson Education inc.

Hyvinkaa \& Rihimaki. 2003. How to Praktice Ecological, Social, and Economic Sustainability in School. Finland: Silverprint.

Janhonen, H. \& Abruquah. 2006. Eco-cultural Theory in the Research of Trans-National Families and Their Daily Life. Finland: University of Helsinki.

Kesuma, D. 2011. Pendidikan Karakter: Kajian Teori dan Praktik di Sekolah. Bandung: Remaja Rosdakarya.

Lickona, T. 1991. Education For Character. New York: Bantam Books.

Nugroho, I. 2010. Nilai-Nilai Pancasila Sebagai Falsafah Pandangan Hidup Bangsa Untuk Peningkatan Kualitas Sumber Daya Manusia Dan Pembangunan Lingkungan Hidup. Jurnal Konstitusi, Volume III, No. 2, November 2010

Poespowardojo, S. \& Hardjatno, N. J. M. T. 2010. Pancasila Sebagai Dasar Negara dan Pandangan Hidup Bangsa. Pokja Ideologi. Lemhannas, Jakarta.

Priyanto, Yuli., et al. 2013. Pendidikan Berperspektif Lingkungan Menuju Pembangunan Berkelanjutan. Wacana Vol. 16, No. 1 (2013) ISSN : 1411-0199

Prugh, T. dkk. 1995. Natural Capital and Human Economic Survival. ISEE Solomons MD. International Society for Ecological Economic.

Putrawan, M. I. 2014. Konsep-Konsep Dasar Ekologi Dalam Berbagai Aktivitas Lingkungan. Bandung: Alfabeta.

Seels, B.B. \& Richey, R.C. 1994.Instructional Technology: The Definition and domains of the field. Washinton DC: AECT.

Setiaji, K. 2014. "Pendidikan Ekonomi Berwawasan Lingkungan Di Universitas Konservasi (Studi Kasus Integrasi Nilai Konservasi Di Fakultas Ekonomi UNNES)". Prosiding Pluralisme Dalam Ekonomi dan Pendidikan. Volume 1 Tahun 2014, ISSN 2407-2468, Jurusan Ekonomi Pembangunan FE-UM 
Taufiq, M., dkk. 2014. Pengembangan Media Pembelajaran IPA Terpadu Berkarakter Peduli Lingkungan Tema "Konservasi" Berpendekatan Science-Edutainmen. Jurnal Pendidikan IPA Indonesia (JPII) Volume 3 No. 2

Wahjoedi. 2014. Pendidikan Ekonomi Berwawasan Lingkungan, Kebutuhan Generasi kini dan Masa Depan. Prosiding Seminar Nasional Forum Pimpinan Pascasarjana LPTKN se-Indonesia, Halaman 372-382. ISSN 23560754,Program pascasarjana Universitas Negeri Ganesah. Bali 21-23 Juni 2014. 